O AUTOR

Mário de Andrade (1893-1945)

Participa da Semana de Arte Moderna, em São Paulo, de 13 a 18 de fevereiro de 1922; faz parte do grupo da revista Klaxon, publicando poesias e críticas de literatura, artes plásticas, cinema e música. Realiza diversas viagens etnográficas pelo Interior do Brasil, recolhendo músicas, contos e danças populares. É autor de diversas modinhas e de importantes estudos sobre música. Colabora em diversos jornais e revistas do Rio de Janeiro e São Paulo. Autor, entre outros, de Paulicéia desvairada (1922), Losango Cáqui (1926), Amar, verbo intransitivo (1927), Clã do Jaboti (1927), Macunaíma (1928), Pequena História da Música (1942), Aspectos da literatura brasileira (1943), Lira paulistana (1945, publicação póstuma).

\title{
O POETA COME AMENDOIM ${ }^{1}$
}

(a Carlos Drummond de Andrade)

Noites pesadas de cheiros e calores amontoados...

Foi o Sol que por todo o sítio imenso do Brasil

Andou marcando de moreno os brasileiros.

Estou pensando nos tempos de antes de eu nascer...

A noite era pra descansar. As gargalhadas brancas dos mulatos...

Silêncio! O Imperador medita os seus versinhos.

Os Caramurus conspiram na sombra das mangueiras ovais.

Só o murmurejo dos cre'm-deus-padre irmanava os homens de meu país...

Duma feita os canhamboras perceberam que não tinha mais escravos,

Por causa disso muita virgem-do-rosário se perdeu...

Porém o desastre verdadeiro foi embonecar esta República temporã.

A gente ainda não sabia se governar...

Progredir, progredimos um tiquinho

Que progresso também é uma fatalidade...

Será o que Nosso Senhor quiser!...

Estou com desejos de desastres... 
Com desejos do Amazonas e dos ventos muriçocas

Se encostando na cangerana dos batentes...

Tenho desejos de violas e solidões sem sentido

Tenho desejos de gemer e de morrer.

Brasil...

Mastigado na gostosura quente do amendoim...

Falado numa língua curumim

De palavras incertas num remeleixo melado melancólico...

Saem lentas frescas trituradas pelos meus dentes bons...

Molham meus beiços que dão beijos alastrados

E depois murmuram sem malícia as rezas bem nascidas...

Brasil amado não porque seja a minha pátria,

Pátria é acaso de migrações e do pão-nosso onde Deus der...

Brasil que eu amo porque é o ritmo do meu braço aventuroso,

$\mathrm{O}$ gosto dos meus descansos,

$\mathrm{O}$ balanço das minhas cantigas amores e danças.

Brasil que eu sou porque é a minha expressão muito engraçada,

Porque é o meu sentimento pachorrento,

Porque é o meu jeito de ganhar dinheiro, de comer e de dormir. 